\title{
Long term fine aerosols at the Cape Grim global baseline station: 1998 to 2016
}

\author{
Jagoda Crawford*, David D. Cohen, Eduard Stelcer, Armand J. Atanacio \\ Australian Nuclear Science and Technology Organisation, Locked Bag 2001, Kirrawee DC, NSW 2232, Australia
}

\section{H I G H L I G H T S}

- $\mathrm{PM}_{2.5}$ sampling was undertaken at the Cape Grim global baseline station since 1992.

- Ion Beam Analysis was used to resolve 23 elements.

- Six source fingerprints have been identified using PMF.

- Higher concentrations of secondary aerosols occur from the mainland fetch.

- However, concentrations are still lower than at more population regions.

\section{A R T I C L E I N F O}

\section{Article history:}

Received 10 February 2017

Received in revised form

27 June 2017

Accepted 4 July 2017

Available online 8 July 2017

\section{Keywords:}

Aerosols

Positive matrix factorisation

Cape grim

Baseline

\begin{abstract}
A B S T R A C T :
Fine aerosol measurements have been undertaken at the Cape Grim global baseline station since 1992. Ion beam analysis techniques were then used to determine the elemental composition of the samples from which source fingerprints can be determined. In this study six source fingerprints were identified to contribute to the measurements of $\mathrm{PM}_{2.5}$ at Cape Grim (from 1998 to 2016); fresh sea salt (57\%), secondary sulfate and nitrates (14\%), smoke (13\%), aged sea salt (the product of $\mathrm{NaCl}$ reactions with $\mathrm{SO}_{2}$; $12 \%)$, soil dust (2.4\%) and industrial metals (1.5\%). Back trajectory analysis showed that local Tasmanian sources of soil dust contributed to the high soil dust measurements. High measurements of secondary aerosols were recorded when air masses were arriving from the Australian mainland, in the direction of the Victorian power stations.

When air masses were arriving from the baseline sector, the maximum concentration of aged sea salt was $1.3 \mu \mathrm{g} / \mathrm{m}^{3}$, compared to overall maximum of $4.9 \mu \mathrm{g} / \mathrm{m}^{3}$. For secondary sulfates and nitrates the maximum concentrations were 2.5 and $7.5 \mu \mathrm{g} / \mathrm{m}^{3}$ from the baseline sector and overall, respectively. While measurements at Cape Grim can be affected from long range transport from mainland Australia and some local Tasmanian sources, the average concentrations of anthropogenic sources are still considerably lower than those measured at more populated areas. For example, at Lucas Heights (located south-west of the Sydney central business district, with little local sources) the average concentrations of secondary sulfates/nitrates and aged sea air were 1.4 and $1.0 \mu \mathrm{g} / \mathrm{m}^{3}$, respectively; compared to average concentrations of 0.8 and $0.6 \mu \mathrm{g} / \mathrm{m}^{3}$, at Cape Grim. The average concentrations of smoke were compatible at the two sites. The impact of primary aerosols from vehicle exhaust at Cape Grim was limited and no corresponding fingerprint was resolved.
\end{abstract}

Crown Copyright $\odot 2017$ Published by Elsevier Ltd. All rights reserved.

\section{Introduction}

Atmospheric particulate matter (PM) acts as cloud condensation nuclei, can scatter and absorb radiation and can have an impact on

\footnotetext{
* Corresponding author.

E-mail address: Jagoda.Crawford@ansto.gov.au (J. Crawford).
}

human health (Heintzenberg, 1985a; Bansah et al., 2016, and references therein). As such, measurement of PM has been an integral part of observations at baseline stations (Heintzenberg, 1985a) which have been established for the purpose of monitoring of background air pollution (WMO, 1978). Measurements of PM at baseline stations can vary from atmospheric condensation nucleus (CN) concentration, cloud condensation nucleus (CCN) concentration, aerosol optical absorption to total suspended particulate mass. 
Heintzenberg (1985a) reviewed PM measurement at five baseline stations in both hemispheres. At that time his recommendation was that multi-species chemical sampling needs to be added to baseline aerosol programs, such that statistically significant fingerprints could be used to identify specific natural and anthropogenic source regions.

Local sources can also contribute to the measurements at a sampling site; for example Hyslop et al. (2013) reported on a data set of $\mathrm{PM}_{2.5}$ measurements (PM with aerodynamic diameters less than $2.5 \mu \mathrm{m}$ ) at Mauna Loa Observatory, where all day measurements were carried out which might contain contributions from local sources, and night only measurements were considered to be representative of Pacific background concentrations. They found that the elements characteristic of soils generally exhibited similar concentrations between night (only) sampling and whole day sampling indicating that Pacific background air masses are responsible for the majority of fine soil aerosols measured at Mauna Loa, whereas local sources were contributing to daytime sulfur concentrations.

Cape Grim, located at the north western tip of Tasmania was established, in 1976, as a global baseline station. A list of atmospheric component measured at Cape Grim can be found at CSIRO (2016). Over the years many varied measurements of PM have been undertaken at Cape Grim. Aerosol measurements were conducted at Cape Grim as part of the first Aerosol Characterization Experiment (ACE 1; Bates et al., 1998), organized by the International Global Atmospheric Chemistry (IGAC) Program. The aim of these experiments is to reduce the overall uncertainty in the calculation of climate forcing by aerosols and to understand the multiphase atmospheric chemical system. The region covered by ACE 1 is detailed in Bates et al. (1998). Huebert et al. (1998) present the concentrations of non-sea-salt sufate (nss), methane sulfonate (MS), ammonium, sodium, nitrate, and a number of other anions and cations from aircraft measurements and measurements undertaken at the Cape Grim baseline station. Most species had a strong vertical concentration gradient, with higher concentrations in the marine boundary layer than in the free troposphere. At Cape Grim, daytime increases of MS (which is photochemically derived) were seen with more constant or decreasing concentrations at night. Quinn and Bates (2005) compare boundary layer aerosol measurements from ACE 1 with a number of other regional studies. Aside from results of ACE 1, aerosol studies of areas downwind from continental source regions were included (Western Europe, North America, Africa, India and Asia). Some of the findings were that sea salt dominates the sub- and supermicron aerosol mass in the remote marine atmospheres. In plumes sourced from continents the nsSOO $^{-}$made up $16-46 \%$ of the submicron aerosol mass and particulate organic matter (POM) was highly variable and makes up from 1 to $51 \%$ of the submicron mass. It is well known that the marine boundary layer (MBL) contains airborne surface-active organic material (Middlebrook et al., 1998). Middlebrook et al. (1998) discusses organic material in aerosols at Cape Grim. Mixtures of sea-salt and organic species were detected in about half of the negative spectra during clean marine conditions and in about $62 \%$ of the negative spectra during polluted conditions. The average organic mass was estimated to be about $10 \%$ of the sea-salt content.

A summary of aerosols measurement campaigns at Cape Grim (prior to 2003) were detailed by Keywood (2003). PM 2.5 sampling, for this study, commenced in July 1992, followed by the application of accelerator based ion beam analysis (IBA) methods used to determine the elemental composition of the $\mathrm{PM}_{2.5}$ samples. Using Principal Component Analysis (PCA; Jollife, 1986) on the elemental composition of the $\mathrm{PM}_{2.5}$ samples (between 1992 and 1998) Cohen et al. (2000) found that $48 \%$ of the total fine mass over the study period was from sea salt. Other sources of $\mathrm{PM}_{2.5}$ identified were smoke, soil and industry.

Here we analyse $\mathrm{PM}_{2.5}$ samples, obtained at Cape Grim, from April 1998 to June 2016. A more recent method is used for the source fingerprint identification and apportionment of the $\mathrm{PM}_{2.5}$ (i.e. Positive Matrix Factorisation, as implemented in the PMF program; Paatero and Tapper, 1994). This is followed by air mass back trajectories analysis to identify the possible source locations and differentiate whether they are local Tasmanian or long range transport from the Australian mainland.

\section{Study site and methods}

\subsection{Study site}

Cape Grim is located at the north western tip of Tasmania $\left(40^{\circ} 41^{\prime} \mathrm{S}, 144^{\circ} 41^{\prime} \mathrm{W}\right)$, an island about $200 \mathrm{~km}$ south of the Australian mainland (Fig. 1). The measurement site is located on top of a $94 \mathrm{~m}$ high cliff, with the Southern Ocean in a south-westerly direction. As such, the baseline sector is defined as the region between 190 and $280^{\circ}$ from the Cape Grim measurement site and air massed arriving from this direction are considered as the least terrestrially affected air masses (e.g. as in Ayers and Ivey, 1988). Also included in Fig. 1 and Table 1 are locations of major point sources of $\mathrm{SO}_{2}$ and $\mathrm{NO}_{\mathrm{x}}$ as identified in the national Pollution Inventory data base (NPI, 2016).

\subsection{Aerosol sampling, elemental analysis and source fingerprint identification}

$\mathrm{PM}_{2.5}$ has been sampled at Cape Grim since 1998 using a $\mathrm{PM}_{2.5}$ system based on the IMPROVE system used extensively in the US. This system employs a $25 \mathrm{~mm}$ diameter Teflon filter and typically samples at a flow rate of $22 \mathrm{~L} / \mathrm{min}$. Twenty-four-hour (midnight-tomidnight) continuous $\mathrm{PM}_{2.5}$ samples are collected twice a week (Wednesday and Sunday). The total $\mathrm{PM}_{2.5}$ mass was obtained with Matteke Toledo MX5 microbalance under laboratory conditions of $22{ }^{\circ} \mathrm{C}$ and relative humidity of $20 \%$ with an uncertainty $\pm 10 \mu \mathrm{g}$, readability $1 \mu \mathrm{g}$, repeatability $0.0008 \mathrm{mg}$. Accelerator-based ion beam analysis (IBA) is used to determine the elemental composition of the $\mathrm{PM}_{2.5}$ samples (Cohen et al., 1996). The concentrations of 22 elements are determined for each sample $(\mathrm{H}, \mathrm{N}, \mathrm{Na}, \mathrm{Al}, \mathrm{Si}, \mathrm{P}, \mathrm{S}, \mathrm{Cl}$,

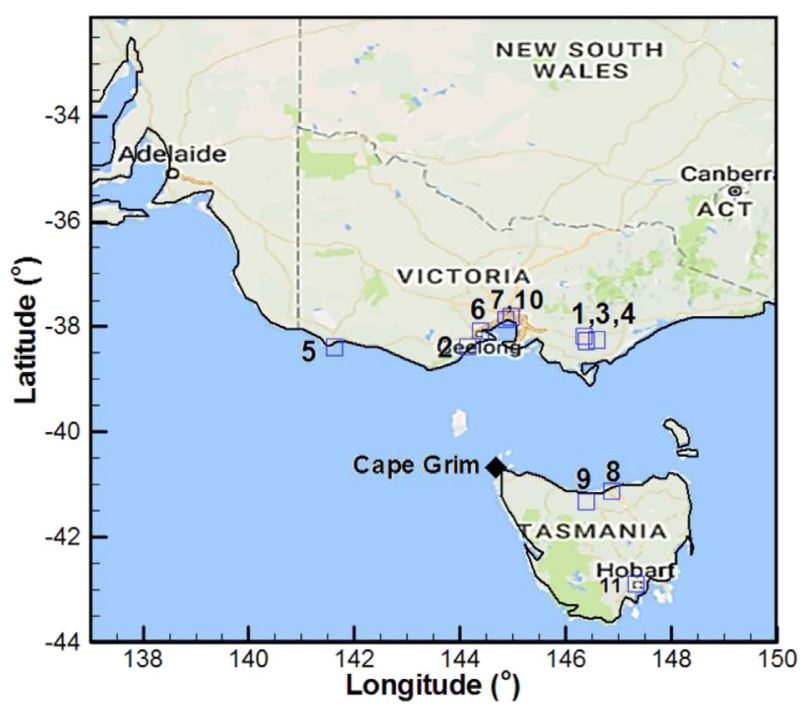

Fig. 1. Location of Cape Grim and major point sources of $\mathrm{SO}_{2}$ and $\mathrm{NO}_{\mathrm{x}}$. Numbers identify locations in Table 1. 
Table 1

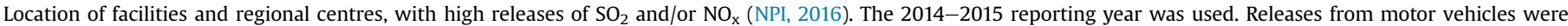
available on a state wide basis (and not by city).

\begin{tabular}{|c|c|c|c|c|c|c|}
\hline & Facility & Location on map & $\mathrm{SO}_{2}(\mathrm{~kg})$ & $\mathrm{NO}_{\mathrm{x}}(\mathrm{kg})$ & Latitude & Longitude \\
\hline Motor Vehicles (Victoria) & Motor Vehicles & & $3,300,000$ & $100,000,000$ & & \\
\hline \multirow[t]{4}{*}{ Power Stations (Victoria) } & Loy Yang Power Stations [Traralgon] & 1 & $81,000,000$ & $36,000,000$ & -38.25 & 146.58 \\
\hline & Alcoa Anglesea Power Station [Anglesea] & 2 & $41,000,000$ & $3,100,000$ & -38.38 & 144.15 \\
\hline & GDF SUEZ Hazelwood [Morwell] & 3 & $21,000,000$ & $29,000,000$ & -38.27 & 146.39 \\
\hline & Energy Australia Yallourn [Yallourn North] & 4 & $20,000,000$ & $15,000,000$ & -38.18 & 146.34 \\
\hline Smelter (Victoria) & Alcoa Portland & 5 & $6,800,000$ & 240,000 & -38.39 & 141.62 \\
\hline \multirow[t]{2}{*}{ Refinery (Victoria) } & Geelong & 6 & $1,200,000$ & 480,000 & -38.08 & 144.38 \\
\hline & Altona & 7 & $2,600,000$ & $1,000,000$ & -37.86 & 144.86 \\
\hline Motor Vehicles (Tasmania) & Motor Vehicles & & & $7,800,000$ & & \\
\hline \multirow[t]{4}{*}{ Manufacturing (Tasmania) } & Rio Tinto Bell Bay Aluminium & 8 & $3,600,000$ & 210,000 & -41.12 & 146.87 \\
\hline & Cement Australia (Railton) & 9 & $2,900,000$ & $1,100,000$ & -41.33 & 146.39 \\
\hline & Melbourne (Victoria) & 10 & & & -37.81 & 144.96 \\
\hline & Hobart & 11 & & & -42.88 & 147.33 \\
\hline
\end{tabular}

K, Ca, Ti, V, Cr, Mn, Fe, Co, Ni, Cu, Zn, Se, Br and Pb). Additionally, a laser HeNe absorption system, assuming a mass adsorption coefficient of $7 \mathrm{~m}^{2} / \mathrm{g}$ is used to determine the black carbon (BC) concentrations. $\mathrm{PM}_{2.5}$ observations between February 1998 and June 2016 were selected for use in this study.

Source type fingerprints were determined using PMF (Paatero and Tapper, 1994), which solves the standard bi-linear factor analysis model. In summary, the standard (bi-linear) factor analysis problem is specified as (Paatero, 2010):

$X=G F+E$

or

$x_{i, j}=\sum_{k=1}^{p} g_{i, k} f_{k, j}+e_{i, j}$

where $X$ is a matrix of measured elements, $G$ and $F$ are factor matrices to be determined, and $E$ is a matrix of residuals. If $n$ observations are available of $m$ elements and assuming $p$ contributing sources, $X$ is an $n$ by $m$ matrix, i.e. $x_{i, j}$ represents the concentration of element $j$ in the $i$ th sample, $G$ is an $n$ by $p$ matrix of source contributions for each sample, $F$ is a $p$ by $m$ matrix of source fingerprints.

The optimisation process minimises the function, $\mathrm{Q}$, while the resolved factor elements, of $\mathrm{F}$ and $\mathrm{G}$, remain non-negative:

$Q=\sum_{i=1}^{n} \sum_{j=1}^{m} \frac{e_{i, j}^{2}}{s_{i, j}^{2}}$

where $s_{i, j}$ is a specified error of the form (Cohen et al., 2010):

$s_{i, j}=M D L_{i, j}+$ Error $_{i, j} \max \left(\left|x_{i, j}\right|,\left|y_{i, j}\right|\right)$

where $M D L_{i, j}$ is the minimum detectable limit, Error ${ }_{i, j}$ is the statistical error, and $y_{i, j}$ is the fitted value i.e. $\mathrm{Y}=\mathrm{GF}$.

The PMF method can result in a number of possible solutions which the user has to choose from based on errors of the fit $(\mathrm{Q}$ value) and how well the factors represent known source types. In this application, between four and seven source fingerprints were examined and it was found that the solution with six source fingerprints best explained the known source types. The expected $\mathrm{Q}$ value is the degrees of freedom of the problem; i.e. $n m-p(n+m)$ (Paatero and Tapper, 1994). Here $n$ (the number of data points) was $1708, m$ (the number of elements) was 23 and selected solution had a $p$ (number of source types to be resolve) of 6 . This implies an expected Q of 28,898; however the final Q was 13411 (about $46 \%$ of the expected $Q$ ), which would indicate that perhaps too many fingerprints were resolved, or the errors $\left(s_{i, j}\right)$ in equation (4) were too large. However, this was not supported as there was no correlation between the resolved fingerprints. Hence, six fingerprints were used for the analysis.

\subsection{Back trajectory analysis}

Back trajectories in the current study were generated, at a starting height of $300 \mathrm{~m}$ above ground level, using HYSPLIT v4.0 (HYbrid Single-Particle Lagrangian Integrated Trajectory; Draxler and Rolph, 2003). The data used with the model was the $1^{\circ} \times 1^{\circ}$ meteorological dataset which is generated by the global data assimilation system (GDAS) model run by the National Weather Service's (NWS) National Centre for Environmental Prediction (NCEP; available at ftp://arlftp.arlhq.noaa.gov/archives/gdas1). Due to the period for which the meteorological data was available, back trajectories were generated from Jan 2001 onwards.

When back trajectories are presented in this work, one back trajectory was determined for each hour of the day (corresponding to the $\mathrm{PM}_{2.5}$ measuring window) and the back trajectories were tracked for 5 days. Back trajectory density maps were generated, for which the horizontal position of the back trajectory (or trajectory endpoint) was determined every $30 \mathrm{~min}$. The region was subdividend into grid cells of $0.5^{\circ}$ by $0.5^{\circ}$ dimension, and if a back trajectory endpoint landed in the grid cell, a grid cell counter was incremented. However, if at a given location, the back trajectory height was above $2000 \mathrm{~m}$, the cell counter was not incremented, as Anthes (1978) points out that the mixed planetary layer over land can be about $2300 \mathrm{~m}$ and Zahorowski et al. (2013) reported mixing layer heights up to $1500 \mathrm{~m}$ in the ocean close to Cape Grim.

To identify if an air mass had passed over a potential point source before arriving at Cape Grim the method of Cohen et al. (2012) was used. Point sources were represented by rectangles and if a back trajectory passed over the rectangle before arriving at the measurement site, it was considered that the point source (rectangle) contributed to the measurement at Cape Grim. The rectangles were $0.2^{\circ}$ by $0.2^{\circ}$ centred at the location of the point source specified in Table 1 .

\subsection{Selecting "baseline" $P M_{2.5}$ concentrations}

To determine an estimate of the concentrations of $\mathrm{PM}_{2.5}$ and source fingerprints associated with least terrestrially affected air masses, the "baseline" sector was used. This was achieved by removing any data for which the back trajectory had passed over land, at any time over the 5 day trajectory history (Tasmania, 
Australian mainland, New Zealand, Africa, and Antarctica), and at the same time ensuring that the wind direction just before arriving at Cape Grim was from the "baseline" sector (between $190^{\circ}$ and $280^{\circ}$ ).

\section{Results and discussion}

\subsection{Total $P M_{2.5}$ mass and elemental concentrations}

The distributions of $\mathrm{PM}_{2.5}$ mass by month of year and then by year are presented in Fig. 2. The minimum and maximum measured values of $\mathrm{PM}_{2.5}$ were 0.62 and $16.96 \mu \mathrm{g} / \mathrm{m}^{3}$, respectively. Higher median concentrations were seen in December, January, April and May. This is further examined when individual source types are considered in section 3.3. Some small variations in the median values were also seen between the years (Fig. 2b), however a $t$-test for the significance in the difference between the means of successive years, showed that the differences were not significant (at $95 \%$ confidence level). The distributions of the elemental composition of the $\mathrm{PM}_{2.5}$ samples are presented in Fig. 3. The highest median concentrations were for $\mathrm{Na}$ and $\mathrm{Cl}$ being the composition of fresh sea salt, and are high due to Cape Grim's coastal location.

\subsection{Identified source fingerprints}

The identified PMF source fingerprints (Fig. 4) are described in the following paragraphs (in descending order of percentage contribution to the total measured $\mathrm{PM}_{2.5}$ mass). The percentage of each element allocated to each fingerprint is presented in Fig. 5 and the time series of the fingerprints are presented in Fig. 6 (where a seasonal trend in some fingerprints is observed; this is discussed further in section 3.3).

Sea (57\%): Dominated by $\mathrm{Na}$ and $\mathrm{Cl}$ with a $[\mathrm{Cl} / \mathrm{Na}]$ ratio of 1.71 , this is close to that expected for fresh sea salt (1.51 and 1.8 in sea water). Almost all the sample $\mathrm{Cl}(99.9 \%)$ was allocated to this fingerprint and $78.9 \%$ of the sodium. High contribution of fresh sea salt is to be expected due to the site's location. Also high wind speeds are experienced (Ayers and Ivey, 1988) and it is known that sea-salt aerosols increase with wind speed (Erickson et al., 1986).

2ndryS (14\%): Dominated by $\mathrm{H}, \mathrm{N}, \mathrm{S}$ and BC, indicative of secondary sulfates and nitrates. All of $\mathrm{N}$ was allocated to this fingerprint and $67 \%$ of the $\mathrm{H}$ and $16 \%$ of the S. Sulfuric acid/ammonium sulfates have previously been detected at Cape Grim (Murphy et al., 1998), however they were less likely from the baseline sector. Ayers et al. (1986) while sampling maritime ("baseline") air masses, found excess sulfate (i.e. not originating from seasalt) which was likely from dimethyl sulfide. However, the estimated concentrations were lower than various locations in the Atlantic and Pacific oceans. Nitrates $\left(\mathrm{NO}_{2}^{-}\right.$and $\left.\mathrm{NO}_{3}^{-}\right)$have also been previously detected in the small size fraction and Derwent et al. (2003) points out that, in general, fine mode nitrate aerosols consist largely of ammonium nitrate. Further, at Cape Grim Andreae et al. (1999) found that ammonia was well correlated with sulfate.

Smoke (13\%): Dominated by $\mathrm{H}$ (from organic sources) and $\mathrm{K}$ (from biomass burning; Yli-Tuomi et al., 2003; Lee et al., 2008; Cohen et al., 2010), with traces of soil and sodium.

SeaAged (12\%): Dominated by Na, S and BC, most likely formed by the chemical reaction of sea spray with sulfate (Lee et al., 1999; Wu et al., 2009). This fingerprint contained $12 \%$ of the sodium and $71 \%$ of the sulfur. This is supported by the finding of Murphy et al. (1998); that sulfur at Cape Grim, in the clean marine conditions was mostly as sodium sulfate.

Soil (2.4\%): Dominated by Si, Ca and Na. It has been suggested that, due to high wind speeds, local soil from the cliff face at Cape Grim (Ayers and Ivey, 1988) is present in the aerosol measurements.

Indmetals (1.5\%): Dominated by Fe and BC. This is considered to have metals associated with industrial releases. Murphy et al. (1997) also found some metals ( $\mathrm{Sn}, \mathrm{Cr}, \mathrm{Fe}$ and occasionally $\mathrm{Pb}$ ) from the baseline sector. Although their primary finding was that iodine was correlated with organics, indicating that the primary source of iodine was from iodine bound to organics in the surfaceactive film on the ocean. Heintzenberg (1985b) described the composition of fine aerosols collected between December 1981 and December 1983, in which $\mathrm{Pb}, \mathrm{Zn}$ and $\mathrm{Cd}$ were found.

\subsection{Seasonal and inter-annual behaviour of source fingerprints}

Back trajectory density maps, by season are presented in Fig. 7. In winter it is more likely for mainland air masses to arrive to Cape Grim, whereas in summer, with the migration of the subtropical high pressure belt south, the air masses are more likely to be arriving from westerly and south-westerly direction. The distributions of concentrations for each source type, by month of year, are presented in Fig. 8. Clear seasonal trend was observed in SeaAged
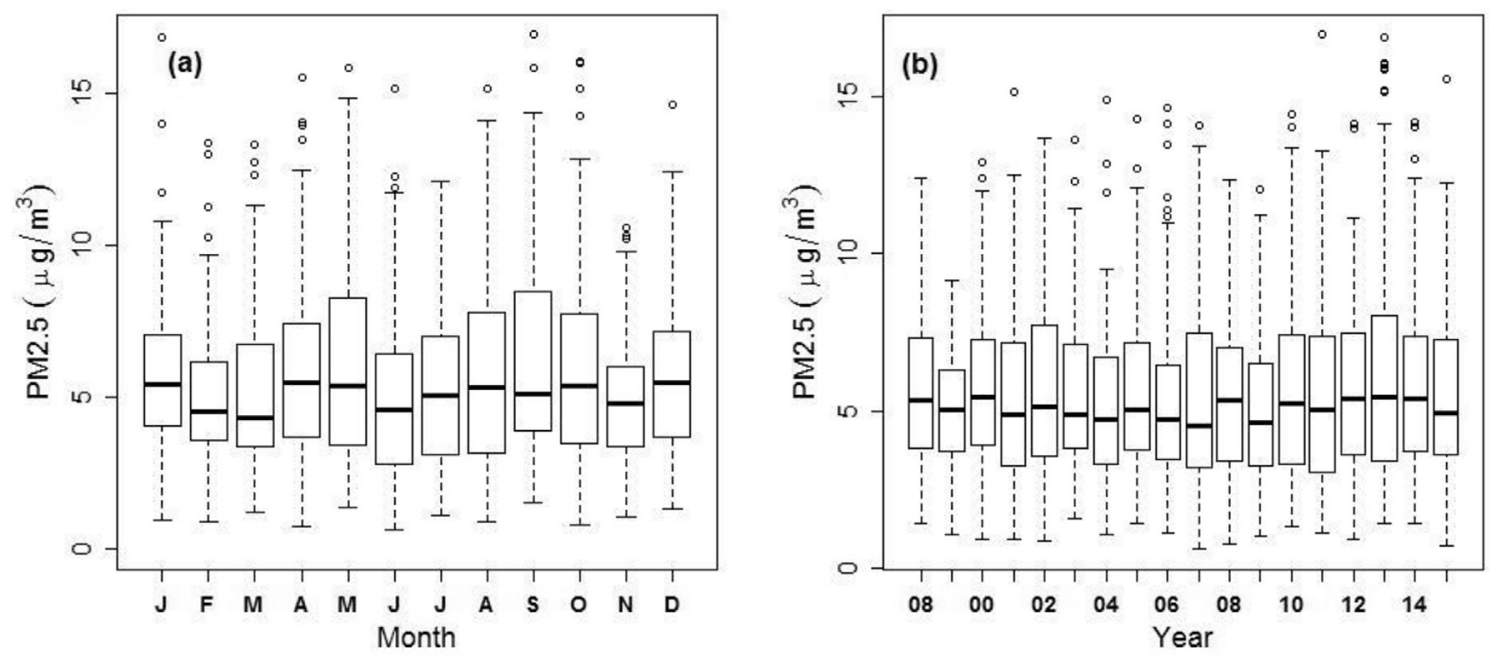

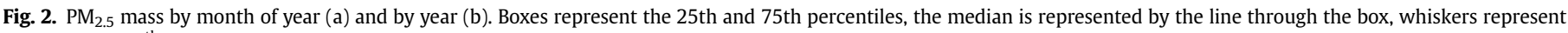
the 10 th and $90^{\text {th }}$ percentiles and the outlier events have also been indicated. 


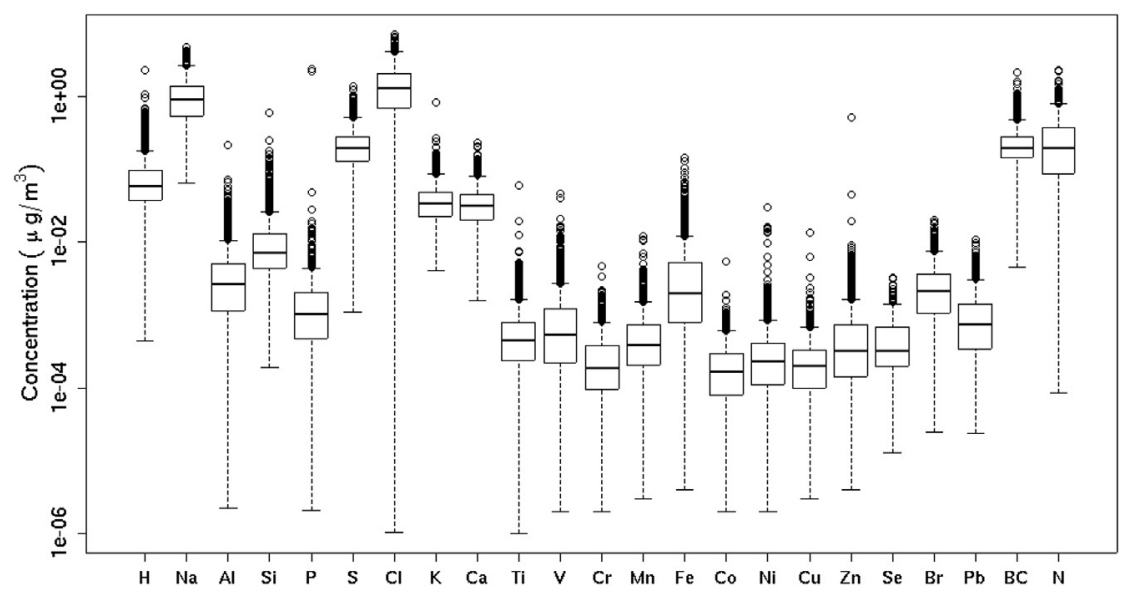

Fig. 3. Distributions of concentrations of the identified elements in the $\mathrm{PM}_{2.5}$ samples (note the y-axis log scale). Boxes and whiskers as in Fig. 2 .

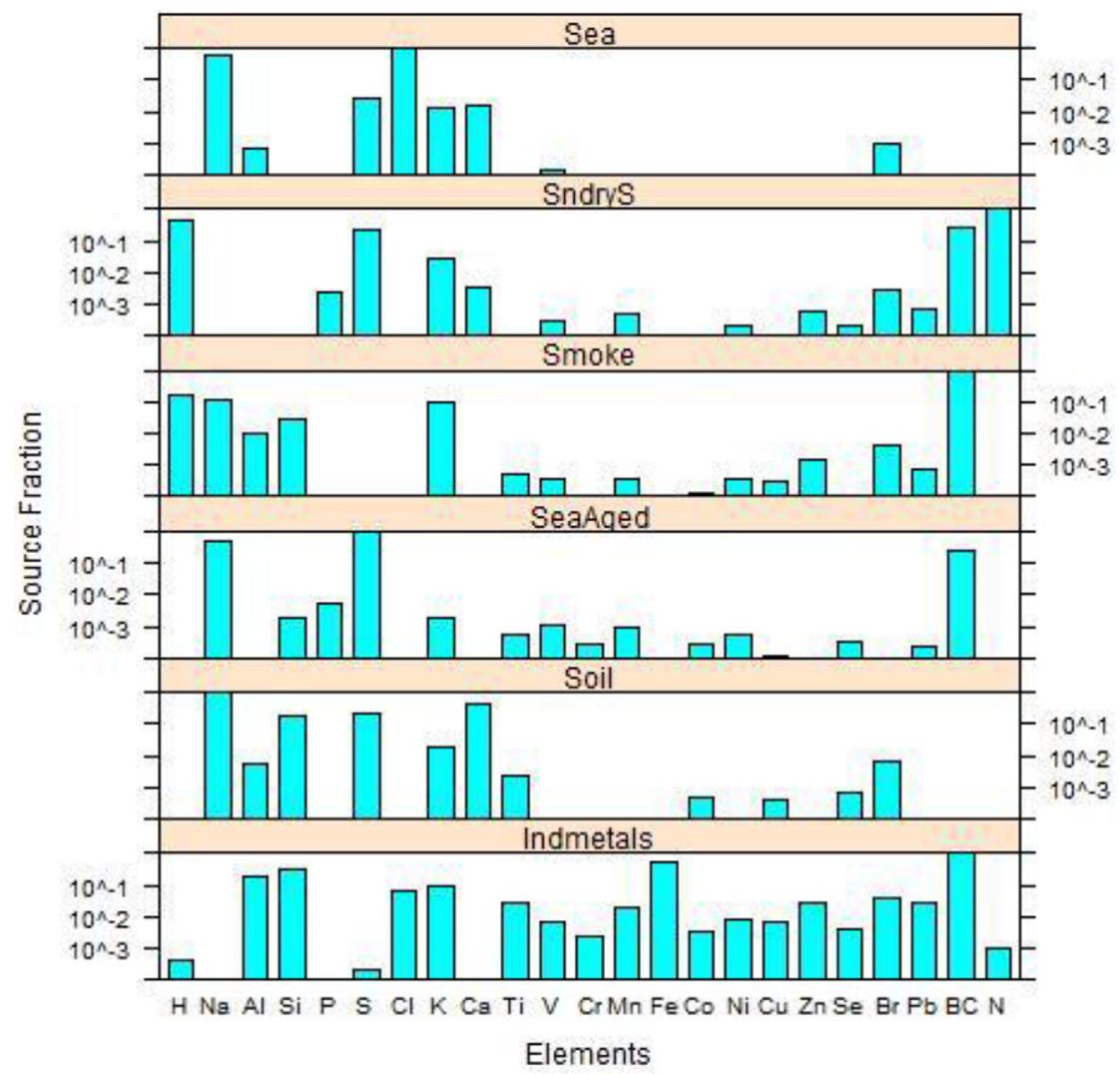

Fig. 4. Elemental composition of each source fingerprint (normalised within each fingerprint).

and Soil, with lower concentrations in winter. The reason for the higher concentrations of Soil in summer is most likely due to the change in predominant fetch region (as seen in section 3.5, higher soil concentrations occur from a southern fetch).

It is known that gaseous dimethylsulfate $\left(\mathrm{CH}_{3} \mathrm{SCH}_{3}\right.$; DMS) enters the marine atmosphere from the ocean (Ayers et al., 1997), where it undergoes a number of photochemical reactions. One of the intermediates is $\mathrm{SO}_{2}$ which is then converted to sulfate aerosols. Ayers et al. (1997) presented results of $\mathrm{SO}_{2}$ measurements at Cape Grim which showed clear seasonal cycle, with higher concentrations in summer (due to DMS oxidation being more efficient at higher temperature). Relatively higher concentrations were seen when air masses were arriving from the Australian mainland or from the island of Tasmania, indicating terrestrial sources. This would explain the larger SeaAged concentrations in summer, with the outlier values, seen in all seasons, corresponding to mainland or Tasmanian fetch. The sulfate summer peaks were also reported by Andreae et al. (1999). The lower concentrations of fresh sea salt, in the warmer months of the year, could be due to loss of $\mathrm{Cl}$ in the formation of SeaAged.

The monthly distribution of 2ndryS in Fig. 10b, closely follows the distribution of measured $\mathrm{NO}_{3}^{-}$at Cape Grim, when all data was used (Keywood, 2003), with higher concentrations in April and May. From Fig. 7b, this corresponds to more local Tasmanian fetch 


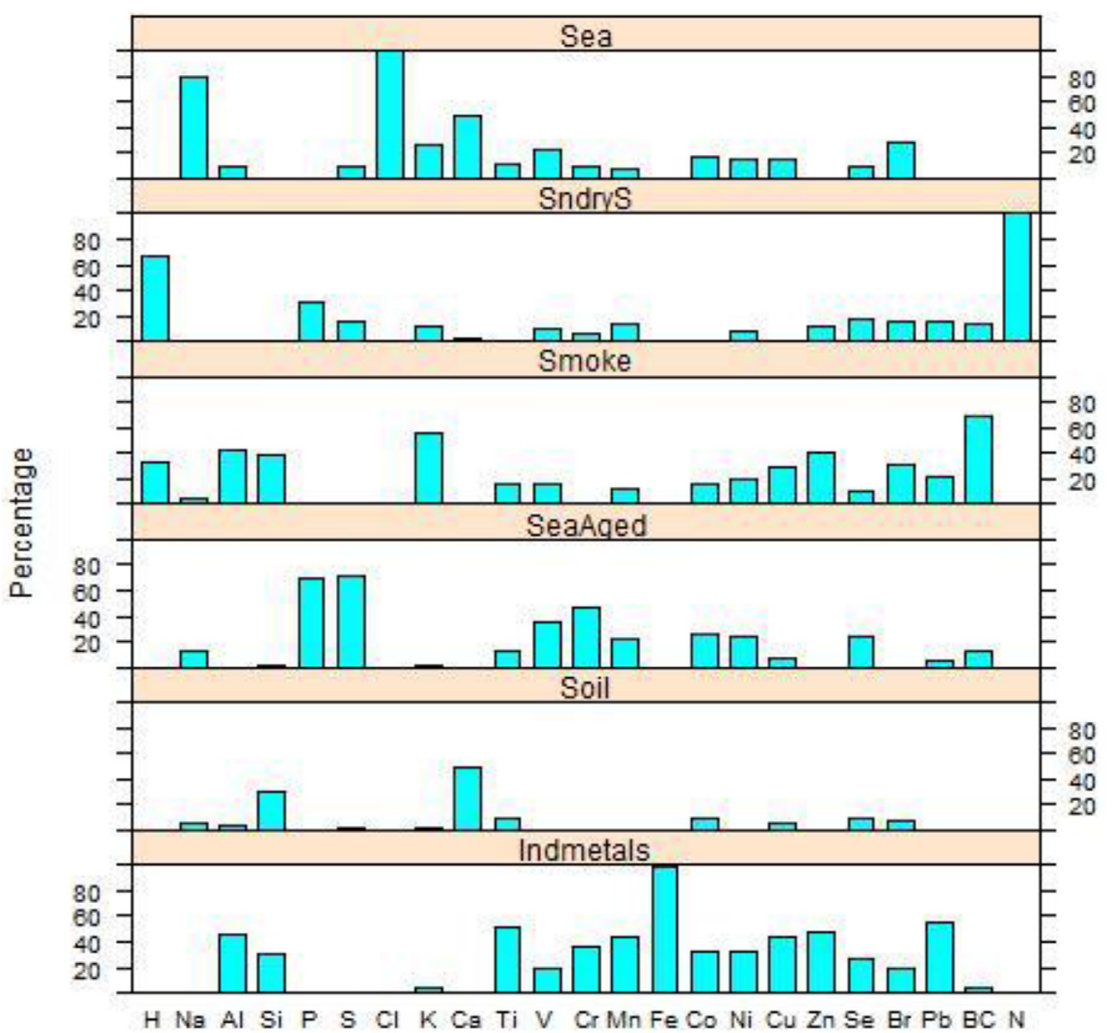

Elements

Fig. 5. Percentage of each element's mass allocated to a fingerprint.
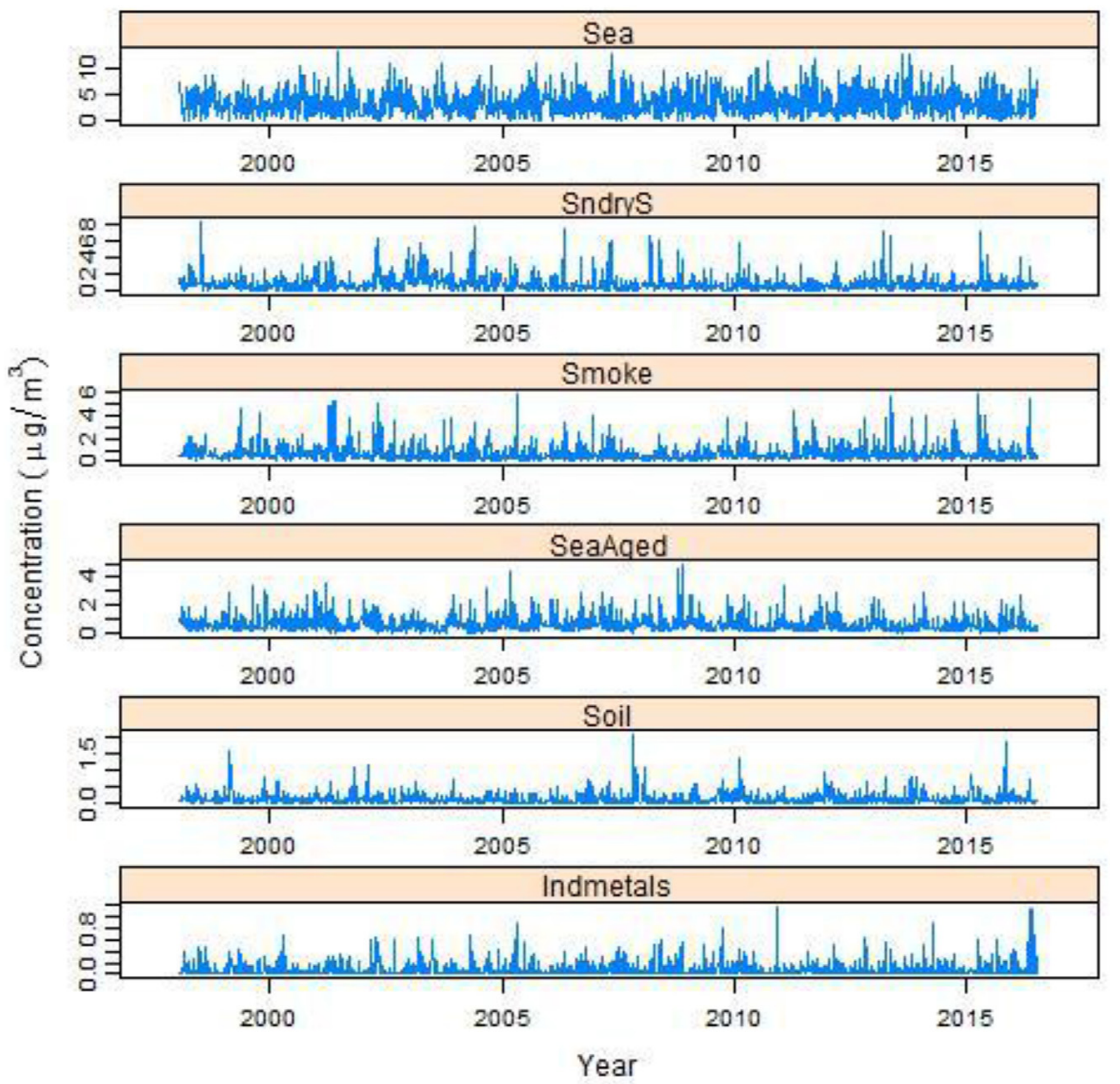

Fig. 6. Time series of each identified source type. 

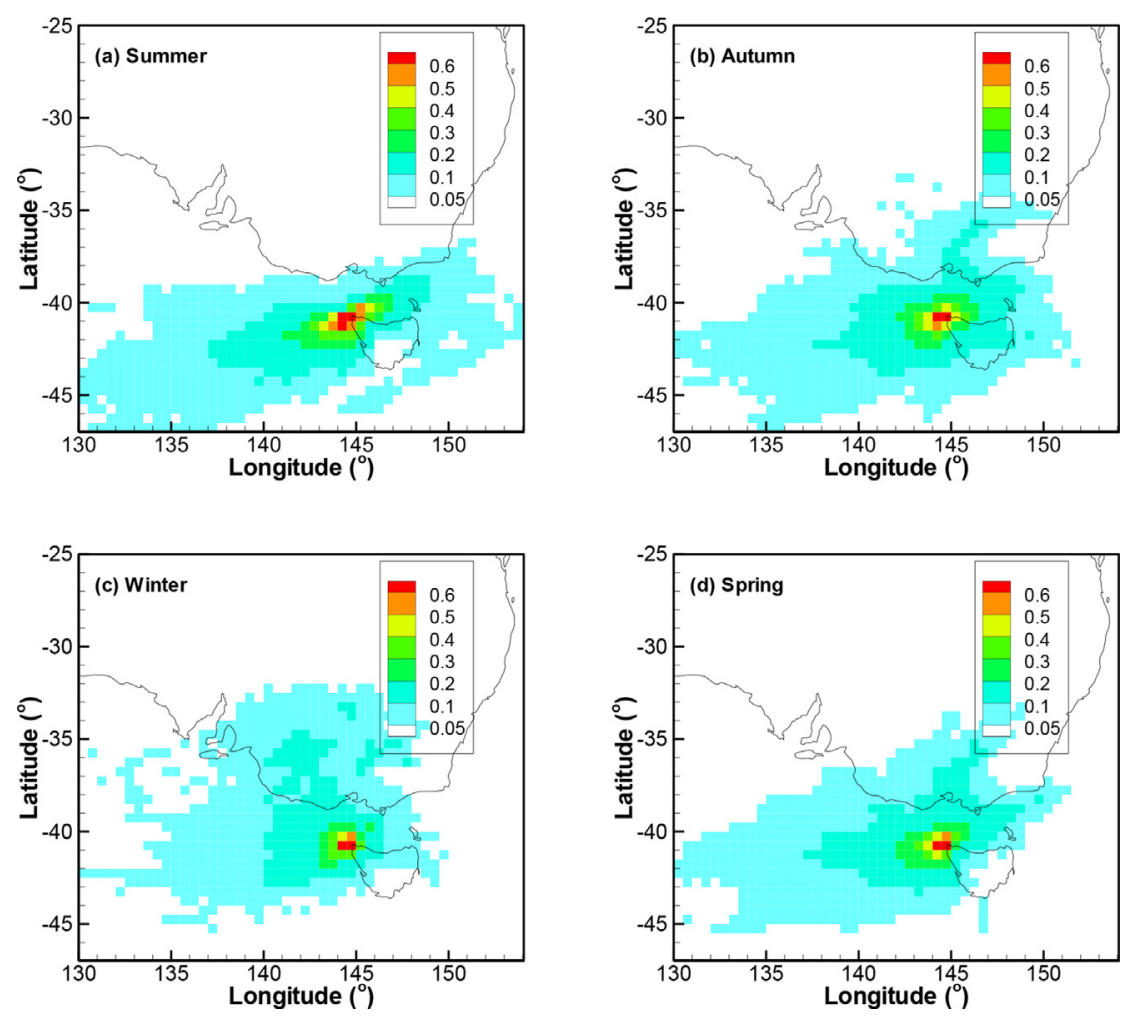

Fig. 7. Back trajectory density maps, at Cape Grim, by season. They have been normalised by the number of back trajectories in each set for easier comparison.

and autumn is a preferred time for prescribed burning which is conducted to reduce the potential damage from wildfires (also supported by the higher Smoke concentrations in this period; Fig. 8c). Aside from primary aerosols, biomass burning is known to contribute to $\mathrm{NO}_{\mathrm{x}}$ and $\mathrm{SO}_{2}$ (Lawson et al., 2015). Heintzenberg and Bigg (1990) reported on concentrations of fine elemental carbon (EC) in samples collected from the "baseline" sector at Cape Grim. High concentrations were seen in Aug to October and a second mode in April and May. Using radon it was concluded that the April-May high EC concentrations were from aged continental emissions. When considering measurements from Cape Grim and Cape Point (S. Africa) the results seem to suggest that the spring maximum could be due to combustion products from biomass burning, at lower latitudes which is then propagated throughout the southern hemisphere.

On an annual basis (Fig. 9) a decreased concentration of SeaAged was seen after 2010 and higher concentrations of 2 ndryS were seen for three consecutive years $(2002,1003$ and 2004). The reason for this is unclear, as no significant known difference in the releases of precursor gasses $\left(\mathrm{SO}_{2}\right.$ and $\mathrm{NO}_{\mathrm{x}}$ ) has occurred for these periods (in the surrounding regions), as reported by the National Pollution Inventory (NPI, 2016).

\subsection{Statistics for "baseline" samples}

The data samples which satisfied the "baseline" criterion, as defined in section 2.4, were selected and the statistics for the whole data set as well as for those data satisfying the "baseline" criterion are presented in Table 2. To give an indication of where the air masses had travelled corresponding to the selected data for the baseline, a back trajectory density map is given in Fig. 10. As expected the highest density of back trajectories occurs in the baseline sector.

Of the 1466 samples (covering Jan 2001 to June 2016), only 104 satisfied the "baseline" condition, of which 39, 24, 17 and 24, were in summer, autumn, winter and spring, respectively. As can be clearly seen from Table 2 , fresh sea salt had higher average values when the air masses had the least terrestrial influence whereas all other source types had lower mean values. The maximum values for sources other than Sea are much lower when the least terrestrially affected air masses are considered. Further, the standard deviation was higher when all the data was considered. The distributions by time of year are presented in Fig. 11.

An interesting observation is that the mean values of the secondary aerosols (2ndryS and SeaAged), when all the data is used, were only 1.5 and 1.7 times the mean values for the "baseline" subset, respectively, whereas for Indmetals the factor was more than three. Some metal ions have previously been observed from the baseline sector indicating long range transport (Keywood, 2003). However, the ratios of the maximum values were more than a factor of 3 for Soil, Smoke and Indmetals, indicating that more recent terrestrial fetch has contributed to these high measurements. In comparison, for a site located southwest of the Sydney central business district (Lucas Heights; with few local sources; Crawford et al., 2016), the average $\mathrm{PM}_{2.5}$ mass was $5.2 \mu \mathrm{g} / \mathrm{m}^{3}$, compatible to that at Cape Grim. However, the average of the fresh sea salt component was $0.5 \mu \mathrm{g} / \mathrm{m}^{3}$, of 2 ndryS was $1.4 \mu \mathrm{g} / \mathrm{m}^{3}$ and old sea air was $1.0 \mu \mathrm{g} / \mathrm{m}^{3}$.

Heintzenberg and Bigg (1990) reported high spring maximum of Elemental Carbon (EC) from the baseline sector at Cape Grim with a second smaller peak in April-May. Higher $50^{\text {th }}$ to 75 th percentile concentrations of "baseline" Smoke were also seen in this study (Fig. 11) for September and April. Heintzenberg and Bigg (1990) suggested that aged continental emissions might contribute to the raise in EC in April, whereas some of the September/October high concentrations were attributed to peaks in combustion products from biomass burning at low latitudes (e.g. southern Africa), moving throughout the Southern Hemisphere. This can be 

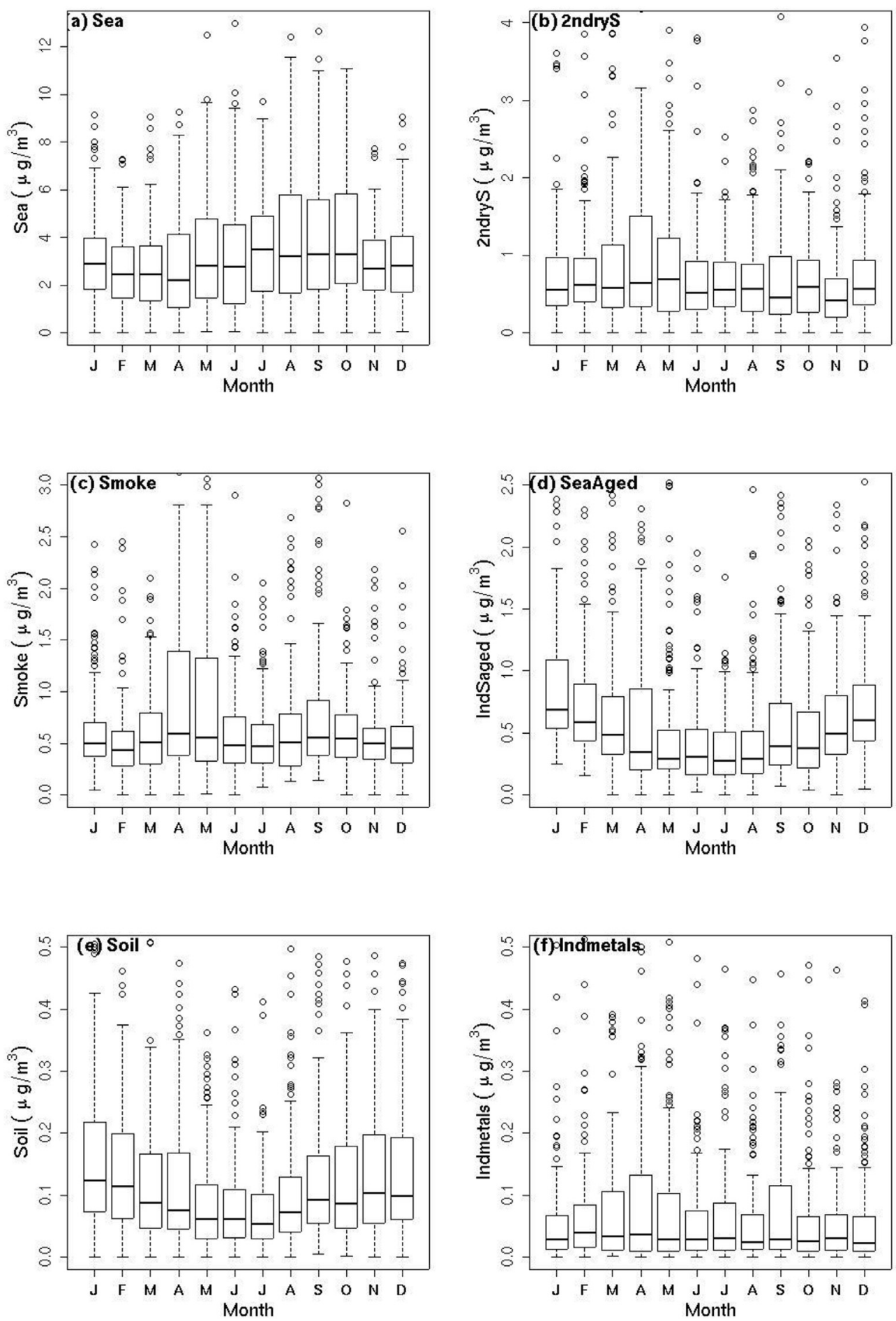

Fig. 8. Distributions of source fingerprint concentration. Box and whisker plots as in Fig. 2.

seen in Supplementary Fig. 1, where the direction of the back trajectory in the last hour was from the baseline sector, but some of the back trajectories had traversed over land prior to that time. In Fig. 10, on the other hand, if the back trajectories had traversed over land at any time over the past five days, those samples were rejected from the baseline classification.

Murphy et al. (1998) reported higher values of sodium sulfate during polluted conditions, where clean air was under those conditions where the wind direction was from the clean air sector $\left(190^{\circ}-280^{\circ}\right)$ and the condensation nuclei were less than $600 \mathrm{~cm}^{-3}$. Here the maximum concentration of SeaAged under baseline conditions was $1.3 \mu \mathrm{g} / \mathrm{m}^{3}$, whereas the maximum measured concentration was $4.9 \mu \mathrm{g} / \mathrm{m}^{3}$.

In the following section we examine the direction from which the high concentrations, of each source type, occur followed by the identification of possible point sources that might have led to the high concentrations. 

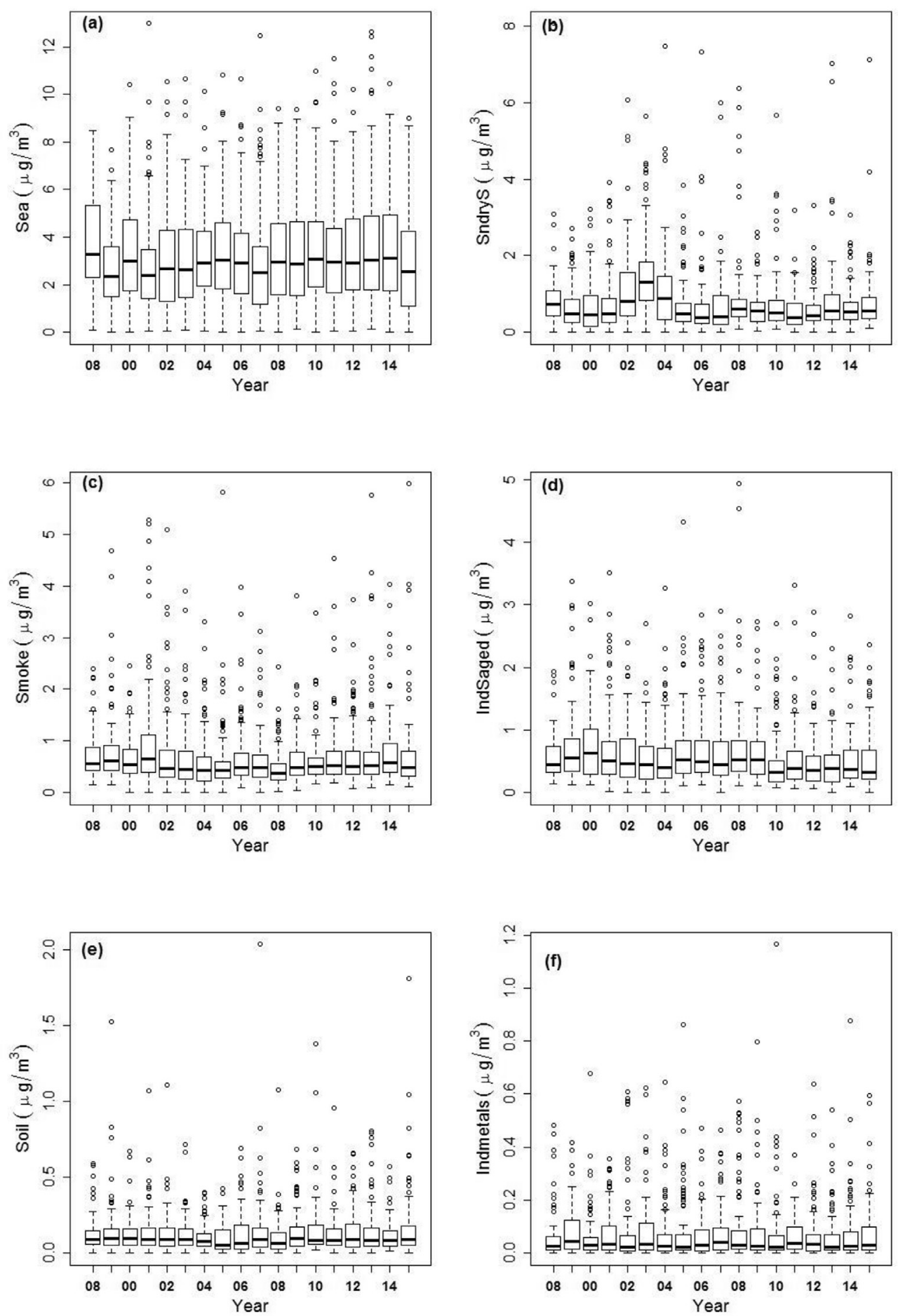

Fig. 9. Annual distributions of $\mathrm{PM}_{2.5}$ sources (a) Sea, (b) 2ndryS, (c) Smoke, (d) SeaAged, (e) Soil and (f) Indmetals. Box and whisker plots as in Fig. 2.

\subsection{Most polluted air masses, by source type}

In an effort to identify the direction from which the highest concentrations of the different sources occur, for each source type back trajectory density maps were generated for back trajectories corresponding to concentrations greater than two standard deviation above the mean (i.e. 7.8, 2.6, 2.1, 1.7, 0.4, $0.3 \mu \mathrm{g} / \mathrm{m}^{3}$, for Sea, 2ndrys, Smoke, SeaAged, Soil and Indmetals, respectively). Note that, aside from fresh sea salt, these values are higher than the corresponding maximum value recorded for the baseline sector.

The highest Sea concentrations were derived from a westerly direction (Fig. 12a) corresponding to the predominant wind direction at Cape Grim (Fig. 7). This well corresponds to the direction of high $\mathrm{Na}^{+}$reported by Keywood (2003). The 2ndryS factor contained all the nitrogen and $16 \%$ of the sulfur. The NPI reports that the highest emissions of $\mathrm{NO}_{\mathrm{x}}$ result for vehicle exhaust, followed by power generation. High concentrations for 2ndryS occur when the back trajectories travelled from the Australian mainland from 
Table 2

Statistics (in $\mu \mathrm{g} / \mathrm{m}^{3}$ ) corresponding to "all data" from January 2001 to June 2016 as well as the data for only those samples satisfying the "baseline" condition, in the same period.

\begin{tabular}{llllll}
\hline & Source & Mean & Min & Max & Standard Deviation \\
\hline \multirow{6}{*}{ Baseline } & PM $_{2.5}$ & 4.8 & 0.8 & 13.7 & 2.4 \\
& Sea & 3.6 & 0.6 & 10.7 & 1.9 \\
& 2ndrys & 0.5 & 0.0 & 2.5 & 0.5 \\
& Smoke & 0.4 & 0.0 & 0.9 & 0.2 \\
& SeaAged & 0.4 & 0.0 & 1.3 & 0.2 \\
& Soil & 0.1 & 0.0 & 0.2 & 0.0 \\
& Indmetals & 0.02 & 0.0 & 0.2 & 0.0 \\
& PMata & 5.6 & 0.6 & 17.0 & 2.9 \\
& Sea & 3.3 & 0.0 & 13.0 & 2.3 \\
& 2ndryS & 0.8 & 0.0 & 7.5 & 0.9 \\
& Smoke & 0.7 & 0.0 & 6.0 & 0.7 \\
& SeaAged & 0.6 & 0.0 & 4.9 & 0.6 \\
& Soil & 0.1 & 0.0 & 2.0 & 0.2 \\
& Indmetals & 0.1 & 0.0 & 1.2 & 0.1 \\
\hline \multirow{7}{*}{ Data } & & & & &
\end{tabular}

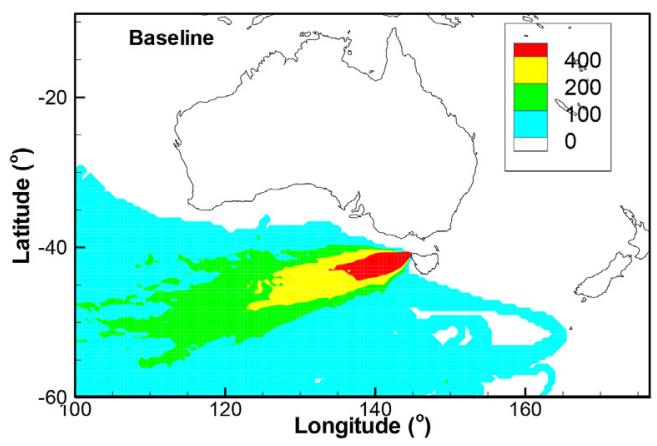

Fig. 10. Back trajectory density map corresponding to samples chosen to represent the "baseline" subset of data.

populated regions around Melbourne (indicating vehicle exhaust contribution) and also the Victorian coal fired power stations at Anglesea, Loy Yang, and Yallourn (Table 1 and Fig. 1). High back trajectory density counts also occurred over Tasmania, south-east of Cape Grim. In Tasmania the NPI reports the highest $\mathrm{SO}_{2}$ releases from non-ferrous metal manufacturing (Table 1) and metal ore mining (located predominantly in north-west Tasmania), corresponding well to high back trajectory counts over the Tasmanian region.

The back trajectory density map for SeaAged (Fig. 12d) showed air masses travelling from the Australian mainland. This factor contains chloride depleted sea air (one mechanism being the reaction of sodium chloride with sulfuric acid to form sodium sulfate; Lee et al., 1999). In the region, the Victorian power stations are the highest contributors of $\mathrm{SO}_{2}$ (NPI, 2016). The chemical reaction would have occurred over the sea in transit from the mainland to Cape Grim.

High Smoke concentrations appear to be predominantly from the Australian mainland (Fig. 12c) and in the direction of woodland indicating bush fires, with some local (Tasmanian) contribution.

From Fig. 12e it can be seen that high soil days show local fetch, consistent with (Ayers and Ivey, 1988, i.e. that soil from the $94 \mathrm{~m}$ cliff contributes to the soil aerosol at Cape Grim). However, metal ore mining activities are located in north-west Tasmania, which have been reported to contribute to primary $\mathrm{PM}_{2.5}$ in Tasmania (NPI, 2016; $100100 \mathrm{~kg}$ for the 2014-2015 reporting period). This would support the higher values in the back trajectory density map along the west coast (Fig. 12e), which also explains the higher soil concentrations in the warmer months of the year (Fig. 8d), as air masses are more likely to be arriving from this region (Fig. 7).

The industry metals fingerprint, Indmetals, indicates local and mainland sources. The Savage River mine and then the manufacturing at Port Latta are located in the north-west of Tasmania (corresponding to areas of higher back trajectory density). The back trajectories from the mainland are in the direction of the Geelong refinery and Victorian power stations. However, this factor contributes to only $1.5 \%$ of the $\mathrm{PM}_{2.5}$.

\subsection{Long distance transport from point sources}

To identify which point sources lead to the highest concentrations of secondary particulate matter at Cape Grim (2ndryS and SeaAged), facilities reported to be contributing to the highest $\mathrm{SO}_{2}$ in the atmosphere were identified from the National Pollution Inventory (NPI, 2016). These were mainly coal fired power stations or metal manufacturing facilities. The highest release of $\mathrm{NO}_{\mathrm{x}}$ in the region were motor vehicles, hence Melbourne and Hobart were also included (Table 1 ). As described in section 2.3, if a back trajectory passed over the rectangle with side of $0.2^{\circ}$ by $0.2^{\circ}$, centred at the facility's specified location in Table 1 , it was assumed that facility contributed to the high measurements at Cape Grim. Originally, coal fired power stations from New South Wales and South Australia were also included but these were found to have little impact to concentrations at Cape Grim, thus they were removed from the final analysis.

The number of times that a source area was crossed by a trajectory when the measured concentration at the monitoring site exceeded the mean concentration by two standard deviation (i.e. 7.8, 2.6, 2.1, 1.7, 0.4, $0.3 \mu \mathrm{g} / \mathrm{m}^{3}$, for Sea, 2ndryS, Smoke, SeaAged, Soil and Indmetals, respectively) is presented in Table 3. These results indicate that the highset contribution to SeaAged occurred when the Victorian power stations are crossed (Loy Yang, Alcoa at Anglesea, Yallourn and Hazelwood).

The highest contributors to 2ndryS (which contained all the nitrogen) were Melbourne and Bell Bay Aluminium and Cement Australia at Raiton (located in Tasmania east of Cape Grim; Table 1 and Fig. 1). From Melbourne the largest contribution to $\mathrm{NO}_{\mathrm{x}}$ would be from vehicle exhaust.

\subsection{High Al concentrations}

Cohen et al. (2000) inspected back trajectories for samples where the Al concentrations were greater than $100 \mathrm{ng} / \mathrm{m}^{3}$ and the $[\mathrm{Al} / \mathrm{Si}]$ ratios were greater than one. They found that a number of these back trajectories had passed over a major aluminium smelting plant at Portland on the Australian mainland over $400 \mathrm{~km}$ north west of Cape Grim.

In this study those samples for which the aluminium concentration was two standard deviations above its mean were selected (i.e. $20 \mathrm{ng} / \mathrm{m}^{3}$ ). Then from these samples, those samples for which the $[\mathrm{Al} / \mathrm{Si}]$ ratio was greater than one were identified (resulting in six samples). The back trajectory density map for this subset of data is presented in Fig. 13, once again showing that the aluminium smelting plant at Portland is a contributor.

\section{Conclusions}

Six source fingerprints were identified to contribute to $\mathrm{PM}_{2.5}$ measurements at the Cape Grim baseline station; fresh sea salt (57\%), secondary sulfate and nitrates (14\%), smoke (13\%), aged sea salt (the product of $\mathrm{NaCl}$ reactions with $\left.\mathrm{SO}_{2} ; 12 \%\right)$, soil dust (2.4\%) and industrial metals (1.5\%).

Back trajectory analysis showed that local Tasmanian sources of soil dust contributed to the high soil dust measurements. High 

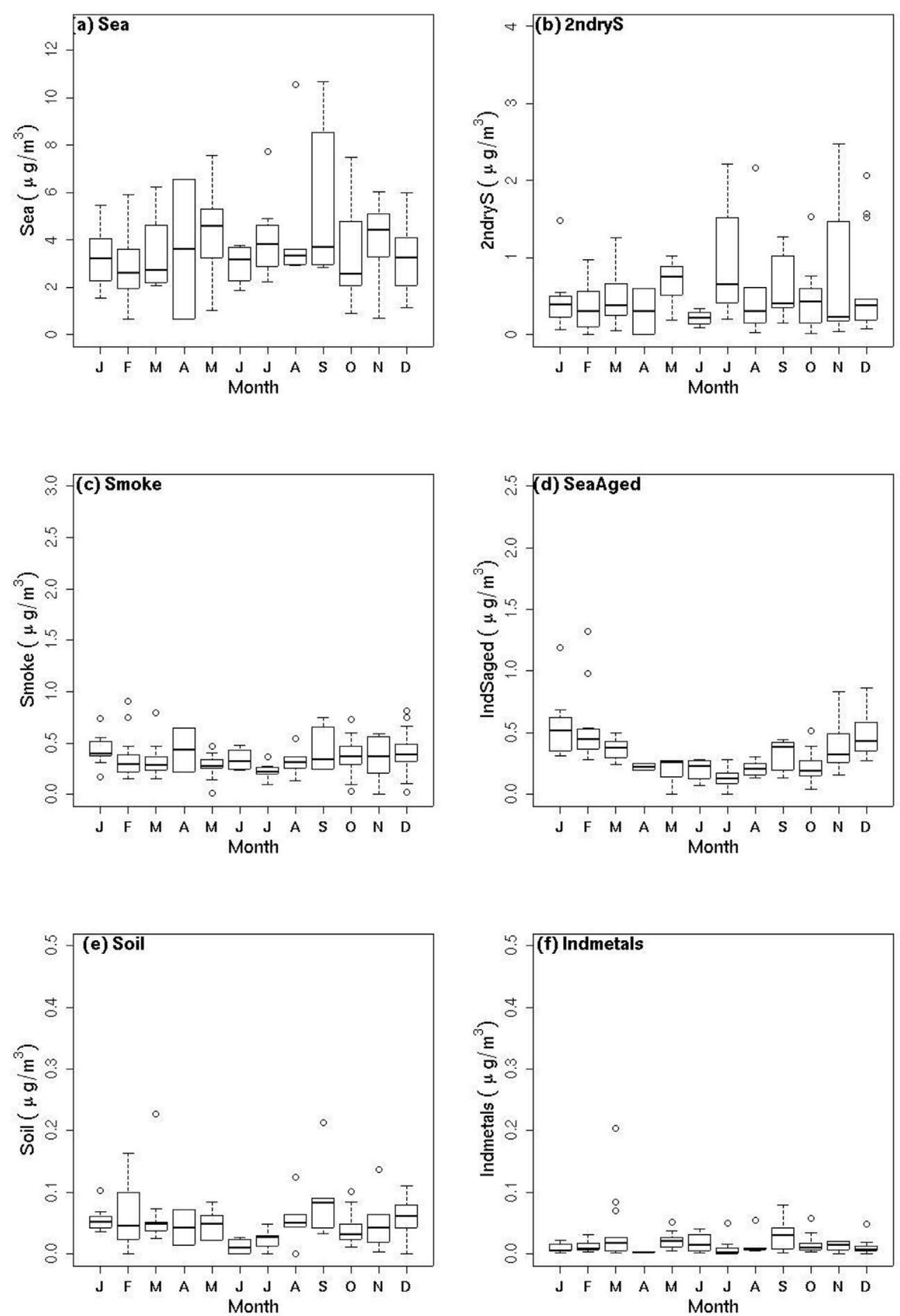

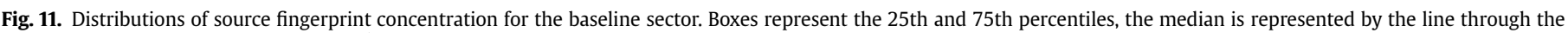
box, whiskers represent the 10 th and $90^{\text {th }}$ percentiles and the outlier events have also been indicated. 

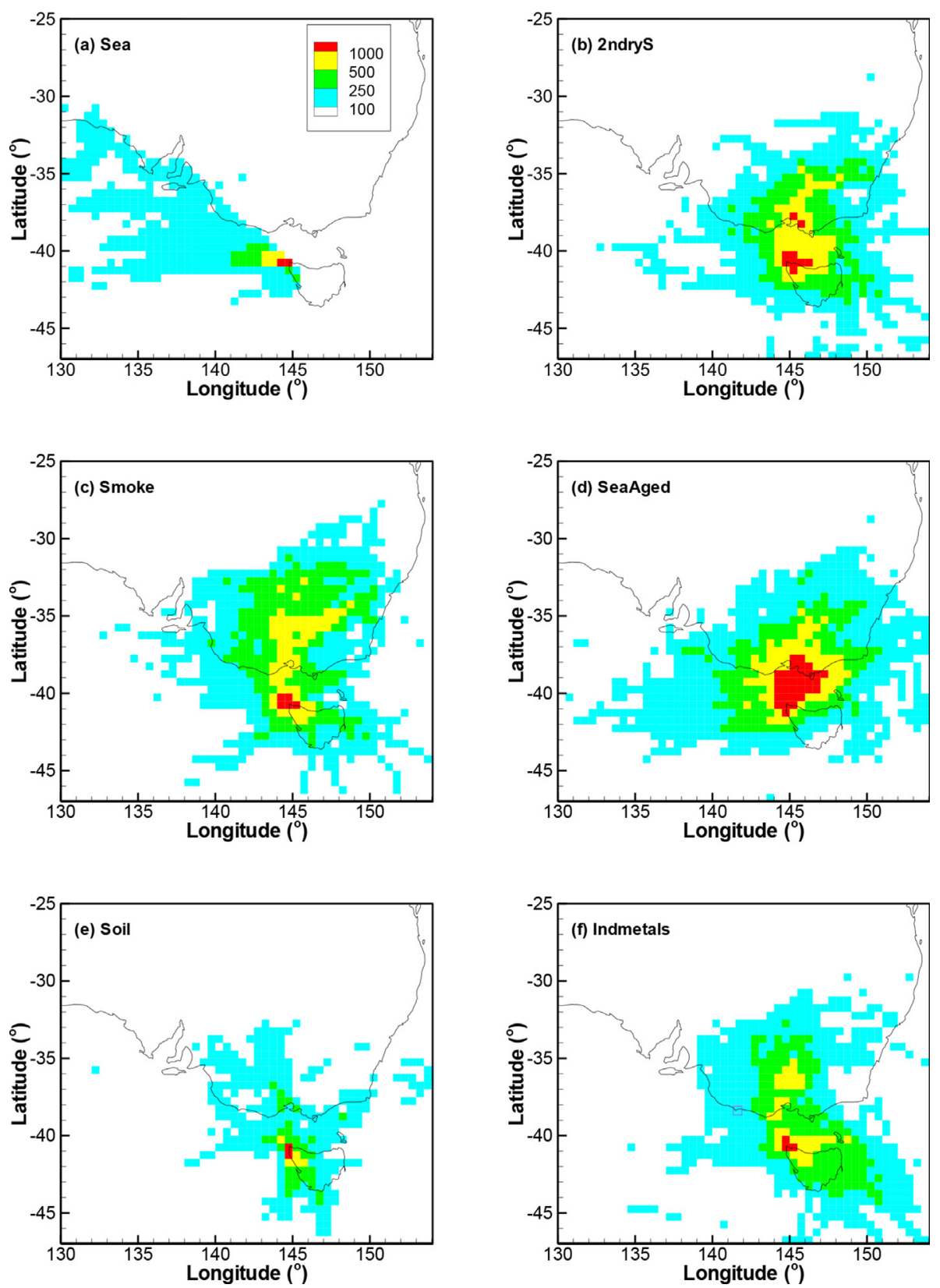

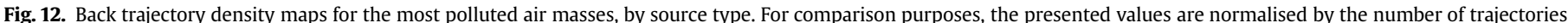
in each set.

Table 3

The number of times that a facility or city was crossed by a back trajectory and high concentrations of the sources were measured at Cape Grim.

\begin{tabular}{|c|c|c|c|c|c|c|c|}
\hline Location & Mass & Sea & Soil & SeaAged & Smoke & 2ndrys & Indmetals \\
\hline Loy Yang Power Stations [Traralgon] & 14 & 1 & 10 & 77 & 25 & 50 & 28 \\
\hline Alcoa Anglesea Power Station [Anglesea] & 21 & 2 & 45 & 83 & 81 & 47 & 69 \\
\hline EnergyAustralia Yallourn [Yallourn North] & 11 & 1 & 9 & 87 & 27 & 44 & 24 \\
\hline GDF SUEZ Hazelwood [Morwell] & 14 & 2 & 10 & 81 & 27 & 43 & 26 \\
\hline Alcoa Portland & 48 & 45 & 14 & 33 & 28 & 21 & 14 \\
\hline Geelong Refinery & 30 & 2 & 37 & 77 & 81 & 36 & 81 \\
\hline Altona Refinery & 24 & 3 & 23 & 62 & 85 & 55 & 44 \\
\hline Rio Tinto Bell Bay Aluminium & 10 & 2 & 25 & 41 & 56 & 72 & 52 \\
\hline Cement Australia (Railton) & 12 & 1 & 22 & 45 & 35 & 67 & 80 \\
\hline Melbourne & 25 & 0 & 20 & 75 & 78 & 69 & 40 \\
\hline Hobart & 4 & 0 & 22 & 4 & 10 & 24 & 41 \\
\hline
\end{tabular}

Locations over which a large number of trajectories had passed when high concentrations of SeaAged and 2ndryS were measured are shaded. 


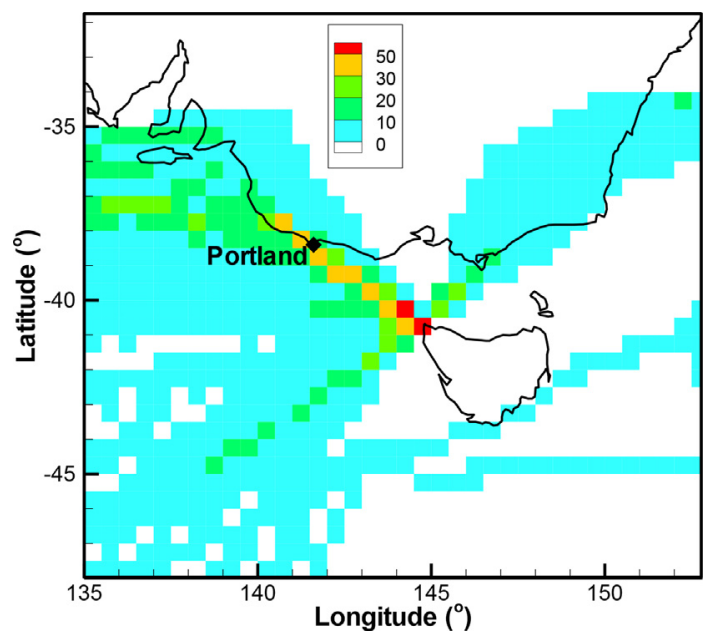

Fig. 13. Back trajectory density map when the $[\mathrm{Al} / \mathrm{Si}]$ ratio was greater than one and the $\mathrm{Al}$ concentration was above its mean plus two standard deviations.

measurements of secondary aerosols were recorded when air masses were arriving from the Australian mainland, in the direction of the Victorian power stations. However, the average concentrations of secondary aerosols were still lower than populated areas, e.g. Lucas Heights (located southwest of Sydney). Although, average concentrations of smoke are compatible and the impact of vehicle exhaust, at Cape Grim, is limited, as no vehicle exhaust fingerprint was resolved.

\section{Acknowledgments}

The authors would like to acknowledge NCRIS funding for accelerators and Centre for Accelerator Science staff for access to their ion beam analysis facilities. The NOAA Air Resources Laboratory (ARL) made available the HYSPLIT transport and dispersion model.

\section{Appendix A. Supplementary data}

Supplementary data related to this article can be found at http:// dx.doi.org/10.1016/j.atmosenv.2017.07.012.

\section{References}

Andreae, M.O., Elbert, W., Cai, Y., Andreae, T.W., 1999. Non-sea-salt sulfate, methanesulfonate, and nitrate aerosol concentrations and size distributions at Cape Grim, Tasmania. J. Geophys. Res. 104, 21,695-21,706.

Anthes, R.A., 1978. The height of the planetary boundary layer and the production of circulation in a sea breeze model. J. Atmos. Sci. 35, 1231-1239.

Ayers, G.P., Ivey, J.P., 1988. Precipitation composition at Cape Grim, 1977-1985. Tellus 40B, 297-307.

Ayers, G.P., Ivey, J.P., Goodman, H.S., 1986. Sulfate and methanesulfonate in the maritime aerosol at Cape Grim, Tasmania. J. Atmos. Chem. 4, 173-185.

Ayers, G.P., Cainey, J.M., Gillett, R.W., Saltzman, E.S., Hooper, M., 1997. Sulfur dioxide and dimethyl sulphide in marine air at Cape Grim, Tasmania. Tellus 49B, 292-299.

Bansah K.J., Dumakor-Dupey N.K., Assan E., 2016. Ambient Particulate Matter - A Review. 4th UMaT Biennial International Mining and Mineral Conference, pp ES 44-54.

Bates, T.S., Huebert, B.J., Gras, J.L., Griffiths, B., Durkee, P.A., 1998. International global atmospheric Chemistry (IGAC) Project's first aerosl characteriztion experiment (ACE 1): overview. J. Geophys. Res. 103, 16,297-16,318.

Cohen, D.D., Bailey, G.M., Kondepudi, R., 1996. Elemental analysis by PIXE and other IBA techniques and their application to source fingerprinting of atmospheric fine particle pollution. Nucl. Instrum. Methods 109, 218-226.
Cohen, D.D., Garton, D., Stelcer, E., 2000. Multi-elemental methods for fine particle source apportionment at the global baseline station at Cape Grim, Tasmania. Nucl. Instrum. Methods Phys. Res. B 161-163, 775-779.

Cohen, D.D., Crawford, J., Stelcer, E., Bac, V.T., 2010. Characterisation and source apportionment of fine particulate sources at Hanoi from 2001 to 2008. Atmos. Environ. 44, 320-328.

Cohen, D.D., Crawford, J., Stelcer, E., Atanacio, A.J., 2012. Application of positive matrix factorization, multi-linear engine and back trajectory techniques to the quantification of coal-fired power station pollution in metropolitan Sydney. Atmos. Environ. 61, 204-211.

Crawford, J., Chambers, S., Cohen, D., Williams, A., Griffiths, A., Stelcer, E., Dyer, L. 2016. Impact of meteorology on fine aerosols at Lucas Heights, Australia. Atmos. Environ. 145, 135-146.

CSIRO 2016. http://www.csiro.au/greenhouse-gases/.

Derwent, R.G., Collins, W.J., Jenkin, M.E., Johnson, C.E., Stevenson, D.S., 2003. The global distribution of seconday particulate matter in a 3-d lagrangian Chemistry transport model. J. Atmos. Chem. 44, 57-95.

Draxler, R.R., Rolph, G.D., 2003. Hybrid single-particle lagrangian integrated trajectory (HYSPLIT), model. http://www.arl.noaa.gov/ready/hysplit4.html.

Erickson, D.J., Merrill, J.T., Duce, R.A., 1986. Seasonal estimates of global atmospheric sea-salt distribution. J. Geophys. Res. 91, 1067-1072.

Heintzenberg, J., 1985a. What can we learn from aerosol measurements at baseline stations. J. Atmos. Chem. 3, 153-169.

Heintzenberg, J., 1985b. Physical and chemical aerosol characteristics in clean air masses at Cape Grim, Tasmania. J. Res. Atmos. 19, 125-129.

Heintzenberg, J., Bigg, E.K., 1990. Tropospheric transport of trace substances in the Southern Hemisphere. Tellus 42B, 355-363.

Huebert, B.J., Howell, S.G., Zhuang, L., Heath, J.A., Litchy, M.R., Wylie, D.J., KreidlerMoss, J.L., Cöppicus, S., Pfeiffer, J.E., 1998. Filter and impactor measurements of anions and cations during the first aerosol characterization experiment (ACE 1). J. Geophys. Res. 103, 16493-16509.

Hyslop, N.P., Trzepla, K., Wallis, C.D., Matzoll, A.K., White, W.H., 2013. Techinal note: a 23-year record of twice-weekly aerosol composition measurements at Mauna Loa Observatory. Atmos. Environ. 80, 259-263.

Jollife, I.T., 1986. Principal Component Analysis. Springer, New York.

Keywood, M., 2003. Aerosol Chemistry at Cape Grim. Baseline atmospheric (Australia) 1999-2000, Pages 31-41, February 2003.

Lawson, S.J., Keywood, M.D., Galbally, I.E., Gras, J.L., Cainey, J.M., Cope, M.E., Krummel, P.B., Frase, P.J., Steele, L.P., Bentley, S.T., Meyer, C.P., Ristovski, Z., Goldstein, A.H., 2015. Biomass burning emissions of trace gases and particles in marine air at Cap Grim, Tasmania. Atmos. Chem. Phys. 15, 13393-13411.

Lee, E., Chan, C.K., Paatero, P., 1999. Application of positive matrix factorization in source apportionment of particulate pollutants in Hong Kong. Atmos. Environ. 33, 3201-3212.

Lee, H.L., Park, S.S., Kim, K.W., Kim, Y.J., 2008. Source identification of PM2.5particles measured in gwangju, Korea. Atmos. Res. 88, 199-211.

Middlebrook, A.M., Murphy, D.M., Thomson, D.S., 1998. Observations of organic material in individual marine particles at Cape Grim during the first aerosol characterization experiment (ACE 1). J. Geophys. Res. 103, 16475-16483.

Murphy, D.M., Thomson, D.S., Middlebrook, A.M., 1997. Bromine, iodine and chlorine in single aerosol particles at Cape Grim. Geophys. Res. Lett. 24, 3197-3200, 1997.

Murphy, D.M., Thomson, D.S., Middlebrook, A.M., Schein, M.E., 1998. In situ singleparticle characterization at Cape Grim. J. Geophys. Res. 103, 16,485-16,491.

National Pollution Inventory 2016. http://www.npi.gov.au/, (releases for 2014-2015; accessed November 2016).

Paatero, P., 2010. User's Guide for Positive Matrix Factorization Program PMF2 and PMF3, Part 1 and 2.

Paatero, P., Tapper, U., 1994. Positive Matrix Factorisation: a non-negative factor model with optimal utilisation of error estimates of data values. Environmetrics 5, 111-126.

Quinn, P.K., Bates, T.S., 2005. Regional aerosol properties: comparisons of boundary layer measurements from ACE 1, ACE 2, Aerosols99, INDOEX, ACE Asia, TARFOX, and NEAQS. J. Geophys. Res. 110, D14102, 14110.11029/12004DJ004755.

WMO, 1978. International Operations Handbook for Measurement of Background Atmospheric Pollution. World Meteorological Organisation, Geneva. No, 491, 110.

Wu, C., Wu, S., Wu, Y., Cullen, A., Larson, T., Williamson, J., Liu, L.-J., 2009. Cancer risk assessment of selected hazardous air pollutants in Seattle. Environ. Int. 35, $516-522$.

Yli-Tuomi, T., Hopke, P.K., Paatero, P., Shamsuzzoha Basunia, M., Landsberger, S., Viisanen, Y., Paatero, J., 2003. Atmospheric aerosol over Finnish Arctic: source analysis by the multilinear engine and the potential source contribution function. Atmos. Environ. 37, 4381-4392.

Zahorowski, W., Griffiths, A.D., Chambers, S.D., Williams, A.G., Law, R.M., Crawford, J., Werczynski, S., 2013. Constraining annual and seasonal radon-222 flux density from the Southern Ocean using radon-222 concentrations in the boundary layer at Cape Grim. Tellus Ser. B 65, 19622,. http://dx.doi.org/10.3402/ tellusb.v65i0.19622. 